\title{
Proceedings of the Institution of Civil Engineers 2003: Bridge Engineering, vol. 156
}

\section{Subject index}

Brickwork \&t masonry

Experimentally-based assessment of masonry arch bridges. Fanning P. J. and Boothby T. E. Sep., 109-116

\section{Bridges}

An integral composite bridge of high skew with end fixity and unusual features. Bell B. Dec., 191-198

Analyses of a composite bowstring truss with tension stiffening. Johnson R. P. Jun., 63-70

Castle Bridge, Weston Super-Mare, UK. James C. Mar., 31-37

Description of the Clifton Suspension Bridge, UK. Barlow W. H. Mar., 5-10

Design and construction of the Bangladesh-UK Friendship Bridge. Collings D., Mizon D. and Swift P. Dec., 181-190

Design of strengthening works for an 1890s steel rail bridge. Waley G., Wilkins S. D. and Barbour H. Jun., 99-107

Dynamic measurements on bridges: design, rehabilitation and monitoring. Cunha Á., Caetano E., Calçada R., De Roeck G. and Peeters B. Sep., 135-148

Dynamics of the Hungerford Millennium footbridges, UK. Fletcher M. S. and Parker J. S. Jun., 57-62

El Ferdan Bridge, Egypt: the world's longest swing bridge. Fuchs N., Tomlinson K. and Buckby R. Mar., 21-30

Experimentally-based assessment of masonry arch bridges. Fanning P. J. and Boothby T. E. Sep., 109-116

Gateshead Millennium Bridge, UK: fabrication, assembly and erection. Butterworth K., Carr D. and Kassabian P. Mar., 11-19

Jiangyin Yangtze River Bridge, China. Young J. Mar., 45-53

Project history of Dublin's River Liffey Bridges. Hamilton A. and Philips M. Dec., 161-179

Real strength of high-performance concrete bridge deck slabs. Taylor S. E., Rankin G. I. B. and Cleland D. J. Jun., 81-90

Section model tests on human-structure lock-in. McRobie A., Morgenthal G., Lasenby J. and Ringer M. Jun., 71-79

Seismic response analysis of long-span steel arch bridges. Nazmy A. S. Jun., 91-97

Synchronised pedestrian excitation of footbridges. Roberts T. M. Dec., 155-160

The construction of Taney Bridge, Ireland. Collings D. and Brown P. C. Sep., 117-124

The reconstructed Lions' Gate suspension bridge, Vancouver. Buckland P. G. and Matson D. D. Sep., 125-133

Weathering steel bridges. Dolling C. N. and Hudson R. M. Mar., 39-44

\section{Composite structures}

An integral composite bridge of high skew with end fixity and unusual features. Bell B. Dec., 191-198

Analyses of a composite bowstring truss with tension stiffening. Johnson R. P. Jun., 63-70

The construction of Taney Bridge, Ireland. Collings D. and Brown P. C. Sep., 117-124
Concrete structures

Real strength of high-performance concrete bridge deck slabs. Taylor S. E., Rankin G. I. B. and Cleland D. J. Jun., 81-90

The construction of Taney Bridge, Ireland. Collings D. and

Brown P. C. Sep., 117-124

Corrosion

Weathering steel bridges. Dolling C. N. and Hudson R. M. Mar., 39-44

Design methods $\mathrm{Ct}$ aids

Dynamics of the Hungerford Millennium footbridges, UK.

Fletcher M. S. and Parker J. S. Jun., 57-62

Real strength of high-performance concrete bridge deck slabs. Taylor S. E., Rankin G. I. B. and Cleland D. J. Jun., 81-90

\section{Dynamics}

Dynamic measurements on bridges: design, rehabilitation and monitoring. Cunha Á., Caetano E., Calçada R., De Roeck G. and Peeters B. Sep., 135-148

Dynamics of the Hungerford Millennium footbridges, UK.

Fletcher M. S. and Parker J. S. Jun., 57-62

Section model tests on human-structure lock-in. McRobie A., Morgenthal G., Lasenby J. and Ringer M. Jun., 71-79

Synchronised pedestrian excitation of footbridges. Roberts T. M. Dec., 155-160

Economics \&t finance

Jiangyin Yangtze River Bridge, China. Young J. Mar., 45-53

Embankments

Castle Bridge, Weston Super-Mare, UK. James C. Mar., 31-37

Field testing \& monitoring

Experimentally-based assessment of masonry arch bridges. Fanning P. J. and Boothby T. E. Sep., 109-116

Geotextiles

Castle Bridge, Weston Super-Mare, UK. James C. Mar., 31-37

Mathematical modelling

Seismic response analysis of long-span steel arch bridges.

Nazmy A. S. Jun., 91-97

Membranes \&t geogrids

Castle Bridge, Weston Super-Mare, UK. James C. Mar., 31-37

Railway systems

Design of strengthening works for an 1890s steel rail bridge. Waley G., Wilkins S. D. and Barbour H. Jun., 99-107 
Rehabilitation reclamation \&t renovation

The reconstructed Lions' Gate suspension bridge, Vancouver. Buckland P. G. and Matson D. D. Sep., 125-133

\section{River engineering}

Design and construction of the Bangladesh-UK Friendship Bridge. Collings D., Mizon D. and Swift P. Dec., 181-190

Project history of Dublin's River Liffey Bridges. Hamilton A. and Philips M. Dec., 161-179

Roads \&t highways

Design and construction of the Bangladesh-UK Friendship Bridge. Collings D., Mizon D. and Swift P. Dec., 181-190

\section{Seismic engineering}

Seismic response analysis of long-span steel arch bridges. Nazmy A. S. Jun., 91-97

\section{Social impact}

Jiangyin Yangtze River Bridge, China. Young J. Mar., 45-53

\section{Steel structures}

El Ferdan Bridge, Egypt: the world's longest swing bridge. Fuchs N., Tomlinson K. and Buckby R. Mar., 21-30

Gateshead Millennium Bridge, UK: fabrication, assembly and erection. Butterworth K., Carr D. and Kassabian P. Mar., 11-19

Weathering steel bridges. Dolling C. N. and Hudson R. M. Mar., $39-44$

\section{Strength $\mathrm{ft}$ testing of materials}

Dynamic measurements on bridges: design, rehabilitation and monitoring. Cunha Á., Caetano E., Calçada R., De Roeck G. and Peeters B. Sep., 135-148

\section{Stress analysis}

Design of strengthening works for an 1890s steel rail bridge. Waley G., Wilkins S. D. and Barbour H. Jun., 99-107

\section{Waterways and canals}

El Ferdan Bridge, Egypt: the world's longest swing bridge. Fuchs N., Tomlinson K. and Buckby R. Mar., 21-30 